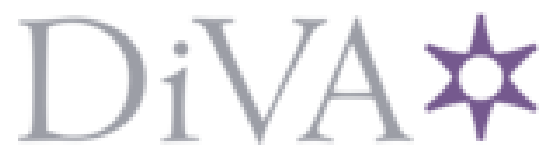

http://www.diva-portal.org

This is the published version of a paper published in International Journal of Academic Research in Business and Social Sciences.

Citation for the original published paper (version of record):

Iddris, F. (2013)

Barriers to Adoption of Mobile banking:Evidence from Ghana.

International Journal of Academic Research in Business and Social Sciences, 3(7): 356-370

https://doi.org/10.6007/JJARBSS/v3-i7/59

Access to the published version may require subscription.

N.B. When citing this work, cite the original published paper.

Permanent link to this version:

http://urn.kb.se/resolve?urn=urn:nbn:se:hh:diva-33539 


\title{
Barriers to Adoption of Mobile banking: Evidence from Ghana
}

\author{
Faisal Iddris \\ School of Business and Engineering, Halmstad University, Sweden \\ DOI: 10.6007/IJARBSS/v3-i7/59 URL: http://dx.doi.org/10.6007/IJARBSS/v3-i7/59
}

\begin{abstract}
The purpose of this research is to investigate the perceived barriers to adoption of mobile banking among consumers, and to assess whether the usage of M-Banking is constraint on the basis of different demographic characteristics such as age, income level, mobile phone usage "experience" and marital status. Data were collected using convenient sampling via selfadministered questionnaire in a large university in the Ashanti region of Ghana. A total of usable 189 responses were collected from non-users of mobile banking and retained for analysis using SPSS version 16 . The main reasons for rejecting M-Banking were explored using simple descriptive analysis, while chi-square tests were used to assess differences between socio-demographic variables and the rejection factors. The result indicates that majority of respondents do not use any kind of mobile banking service. The four main reasons for rejecting M-Banking were: M-banking requires knowledge and learning; M-banking attract additional banking charges; poor telecommunication network; consumer preference for traditional means of banking instead of mobile enabled banking services. The practical implications of this research is the revealing of the main barriers to Mobile banking adoption and suggesting of appropriate marketing strategies to overcome the obstacles to mobile banking adoption.
\end{abstract}

Keywords: Mobile banking, youth market, marketing strategy, Ghana.

\section{Introduction}

The emergence of mobile technology has given rise to new products and services and given the nature of its operations and services, the banking sector is relatively open to innovative technologies (Thulani, Kosmos, Collins and Lyod 2011). Mobile Banking (M-Banking) is one of the emerging Information and Communication Technologies (ICT) element that has changed the operations of the banking sector and banks are eagerly introducing various forms of SMS services for communication and transaction purposes. M-Banking refers to the execution of financial services using mobile communication techniques together with mobile devices (ITU, 2011). Banks are introducing M-Banking in order to take advantage of high mobile phone penetration around the world and more specifically in Africa (Tiwari \&Buse, 2007). The simplicity of using mobile phones to send and receive money and make payments anywhere has the potential in helping in an effort in making Ghana's economy a cashless one. The wider acceptance and usage of M-Banking can result in increase in business and economic growth 
through mobile commerce promotion, enhancing individual, business and national productivity as a whole.

The latest data released by the National Communications Authority (NCA.com, 2013) shows that the total mobile subscriber is about 25 million towards the last part of year 2012. This figure represent 100 percent mobile subscriber base the first of its kind in Africa. The high mobile penetration is an indication of huge market potential for marketing managers who want to target mobile phone users. Tobbin (2012), adoption of mobile banking services can greatly widen the market reach of financial services to the poor and rural population in Africa. In Ghana, eleven out of twenty nine licensed banks have introduced M-Banking as additional product in their quest to capture large market share from both banked and unbanked Ghanaian population.

Some of the popular research conducted in the field of M-banking includes study by Pu"schel, Mazzon, F. and C. Hernandez (2010) who investigated the adoption intention of M-Banking among consumers in Brazil. They discovered that compatibility with life-style, is one of the most important factors to be considered by a manager when launching new mobile services including M-Banking.

Similarly, a study by Laforet and Li (2005), investigated consumers' attitudes towards online and M-Banking in China. Security was found to be the most important determinant for consumer adoption of mobile banking among Chinese and the main reasons for rejection of Internet banking were perception of risks, low computer and technological skills and Chinese traditional cash-carry culture.

Brown, Cajee, Davies, and Stroebel (2003), investigated the factors that influence the adoption of M-Banking in South Africa using innovation diffusion theory (IDT). They discovered that relative advantage, trial periods, and consumer banking needs, along with perceived risk, have a major negative influence on the adoption of M-Banking.

In Finland, Laukkanen and Kiviniemi (2010), conducted a study on the role of information in mobile banking resistance. They pointed out that information and guidance offered by a bank has the most significant effect on decreasing the usage barrier, followed by image, value and risk barriers respectively.

A recent study by Akturan and Tezcan (2012), using technology acceptance model (TAM) to investigate the perception and intentions of M-Banking adoption among youth in Turkey. Attitude was found to be major determinant of mobile banking adoption intention. The implication of the discussion so far meant that understanding of the adoption of mobile services such as M-Banking and mobile commerce requires a consideration of a broader range of parameters (Sarker\& Wells 2003). These parameters includes barriers and driving forces towards M-Banking usage among target and potential market. 
The range of services and transactions that can be undertaken using mobile device is likely to increase, and mobile phones are likely to evolve as ubiquitous payment devices (Wilcox, 2009a). Academicians and businesses have a strong believe that M-Banking can take off in the foreseeable future, however consumer perceived certain barriers that need to be overcome (Laukkanen\&Kiviniemi, 2010). Overcoming M-Banking barriers will help generate wider acceptance of delivery of banking services through mobile digital device.

Therefore the focus of this study is to examine the main barriers to M-Banking adoption. Also the paper assesses whether the usage of M-Banking is constraint on the basis of different demographic characteristics, such as age, income level, marital status and mobile phone usage "experience". Findings of this study will be useful for Bank in developing economies in their quest for developing right marketing strategies for users of ubiquitous electronic device like mobile phone.

\section{Research Questions Development and Explanation}

Demographic variables:

Several studies have investigated the relationship between demographics and adoption behaviour with regards to delivering of electronic services (Cruz et al., 2009; Cruz et al., 2010; Laukkanen\&Pasanen, 2008: Meuter et al., 2005), the reason being that electronic products tend to be expensive and difficult to use and requires certain traits among group of users about the benefits and functionality of the innovation.

Munnukka (2007) argued that age, income and education remains good and accurate predictors of buying behaviour, in addition Munnukka (2007), claimed that marital status was found to be significantly associated with level of adoption of mobile communications.

Karjaluoto, Mattila, and Pento (2002), in their study revealed that demographic factors are major determinants of Internet banking, because they found a typical user of Internet banking in Finland to be highly educated, relatively young and wealthy person with good knowledge of computers and especially the Internet.

Recent study by Iddris (2012), shows that prior experience of using mobile phone influence both attitude and intention to use mobile commerce in B2C transactions. In that study it was revealed that prior experience had the strongest tendency to predict the usage of Mobile commerce. In addition Karjaluoto et al., (2002), evinced that prior experience with computers and technologies and attitudes towards computers influence both attitudes towards online banking and actual behaviours. Goldsmith (2001), intimated that prior experience of using related services or products is believed to have a significant influence on buying behaviour.

Following the discussions above, a number of research questions based on demographic variables, literature reviewed and general objectives of this research were developed.

RQ1 What are the main barriers to adoption of M-Banking?

RQ2 How can the income level of the respondents influence rejection of M-Banking?

RQ3 How can the marital status of the respondents influence rejection of M-Banking?

RQ4 How can the Age of the respondents influence rejection of M-Banking? 
RQ5 How can the gender of the respondents influence rejection of M-Banking?

RQ6 How can the number of years 'experience' of using mobile phone influence rejection of M- Banking?

\section{Research Methodology}

The questionnaire utilised five-point Likert scale to measure the variables. Scales to measure each variables were developed based on prior studies for example (Cruz et al., 2009; Cruz et al., 2010; Laukkanen\&Pasanen, 2008: Meuter et al., 2005) as much as possible. Some of the measures were modified to adapt to this research based on focus group conducted with users and non-users of $\mathrm{M}$-banking to reveal differences in opinions regarding $\mathrm{M}$-banking adoption. The questionnaire included three parts. Part A covered mobile phone usage, Part B included series of 15 statements that covered barriers to adoption of M-Banking derived from the focus group (See table 3 ) and part $C$ covers the socio-economic factors. Responses to each statement in part $B$ of the questionnaire were on a five-point Likert scale ranging from strongly disagree (1) to strongly agree (5). The questionnaire items were directed at non-users of M-banking, since they were the main focus of this study. The questionnaire was pilot tested with sample of 20 participants. The participants were encouraged to make useful suggestions concerning ambiguous question items for clarity and ease of understanding. After pilot testing, the suggestions and corrections from the participants were incorporated into the final questionnaire. The participants for the pilot testing were excluded from the final sample.

The questionnaire were administered in a large university in Ashanti region of Ghana in the month of November, 2012. A convenient sampling method was used and the rational for using student sample in this study was due to widespread usage characteristics of mobile devices for communication among youth especially at tertiary educational institutions.

\section{Results and Analysis}

Scale reliabilities for all the 34 items on the questionnaire items is close to 0.84 , an acceptable level consistent with previous findings.

Table 1 contains information about the names of the M-Banking and the names of the Banks offering these services. In Ghana eleven out of twenty nine licensed banks are offering MBanking.

Table 1. Banks and M-Banking services in Ghana

\begin{tabular}{llll}
\hline \multicolumn{1}{c}{ Bank } & Name of M-Banking & \multicolumn{1}{c}{ Bank } & Name of M-Banking \\
\hline Zenith Bank & Z-Mobile & Standard Chartered & Mobile banking \\
GCB & Mobile banking & UniBank & 'Uni-Mobile \\
Carl Bank & SMS Banking & Prudential Bank & SMS Banking \\
ECOBANK & SMS Banking & Fidelity & SMS Banking \\
Intercontinental & I-Mobile & Barclays Bank & Mobile Banking \\
UBA & U-Mobile & &
\end{tabular}




\section{Sample}

A total of 215 responses were collected and 32 were discarded because of incompletion and the respondents were already using their mobile phones for M-banking transaction. The remaining 183 were retained for analysis using SPSS version 16. Within the sample 68 percent of the respondents were male and 32 percent were female, nearly 96 percent of the respondents falls within 25-35 age group. Almost 26 percent of the respondents were married, 73 percent were unmarried and missing values constitute the remaining items. Almost 37 percent of the respondents earn less than GHc 200. About 78 percent of the respondents have been using mobile phones (experience) for more than 5 years. The detailed information is contained in table 2 below.

Table 2 Demographic Profile

Variable

\section{Frequency}

124

Male

Female

Age

Less than 21

$21-25$

$26-35$

$36-45$

50 and above

Marital Status

Unmarried

Married

Internet connection on mobile phone

Yes

No

Income level (Monthly)

$<$ GHC200

GHC2OO - GHC400

GHC401 - GHC600

GHC601 - GHC800

GHC801 - GHC1000

GHC1001 - GHC1200

GHC1201 - GHC1400

$>$ GHC1401
58

68.1

31.9

9

4.9

75

79

15

4

41.2

43.4

8.2

2.2

121

74.4

42

25.6

134

75.3

40

22.5

53

36.6

25

17.2

22

15.2

22

15.2

10

6.9

1

2

.7

1.4

5

3.4 
No of years of using Mobile phone (Experience)

$<1$ year

1-3 years

3-5 years

$>5$ years

Type of Mobile Internet connection

MTN

Vodafone

Airtel

Tigo

Type of mobile phone

iPhone 3G

Samsung

Blackberry

Sony Ericson

RLG

TECHNO

Nokia

Others
109

20

14

2

8

32

6

11

4

30

52
5.0

8.4

6.7

78.8

73.8

13.5

9.5

1.4

Simple statistical analysis was used to determine the means scores, standard deviations and analysis of important variables. The identification of barriers to the adoption of M-Banking were analysed in two ways. The first was a direct method based on the respondents' average scoring of the importance of list of 15 possible reasons for rejecting M-banking using a scoring index of 1 to 5 described earlier. These factors were adapted from previous studies. The second method was cross tabulation of demographic factors: Marital status, Age, Income level, Gender and Number of years (experience) against the rejection factors identified in table 3 ,

RQ1 What are the main barriers to adoption of M-Banking?

Respondents were asked to rate the importance of M-Banking rejection factors. As presented in table 3, the highest barrier was M-banking requires knowledge and learning (3.64), Mbanking attract additional banking charges was the second highest barrier (3.52), followed by poor telecommunication network (3.25). 
Table 3 M-Banking rejection factors

\begin{tabular}{llll} 
& Reasons for rejecting M-Banking services & Mean & SD \\
\cline { 2 - 4 } 2 & M-banking requires knowledge and learning & 3.64 & 1.518 \\
3 & M-banking attract additional banking charges & 3.52 & 1.553 \\
4 & Poor telecommunication network & 3.25 & 1.725 \\
5 & I prefer to go to bank branches instead of using M-Banking services & 3.18 & 1.744 \\
& My missing mobile phone can be used by third party to steal money & & \\
6 & from my bank account & 3.17 & 1.744 \\
7 & I don't have sufficient balance in my account & 3.03 & 1.792 \\
8 & Cost of purchasing mobile phone suitable for m-banking is high & 2.97 & 1.511 \\
9 & M-banking is difficult to use & 2.70 & 1.815 \\
10 & I am unaware about mobile banking & 2.61 & 1.666 \\
11 & My bank will send me unnecessary text messages & 2.55 & 1.633 \\
12 & None of my friends is using mobile phone for banking transactions & 2.54 & 1.545 \\
13 & My bank do not offer m-banking & 2.40 & 1.630 \\
14 & Mobile phone battery may run down can run down during & 2.31 & 1.790 \\
& transactions & 2.16 & 1.756 \\
15 & I don't have bank account & 1.98 & 1.910 \\
\hline
\end{tabular}

Considering the three most important rejection factors based on the highest mean scores obtained, financial institutions offering M-Banking need to adopt marketing strategy that can educate potential customer on the usage of M-Banking and if possible team up telecommunication companies to ensure vibrant and effective telecommunication services, since telecommunication services is the platform upon which Banks can offer M-Banking.

To examine if socio-economic variables influence rejection of M-Banking services, the rejection factors were cross tabulated against the demographic variables and the results are presented in Table 4. Meaningful conclusion can be derived from the analysis on the basis of frequencies and chi-square values. The chi-square values help in determining the statistical significance and the strength of the association of the cross tabulated variables (Malhotra, Naresh\& Birks, 2008). 
Table 4 Present barriers by socio-demographic variables of the respondents

\begin{tabular}{|c|c|c|c|c|c|c|c|}
\hline Frequency & Chi-Square $x^{2}$ (sig.) & \multirow[b]{2}{*}{$\mathrm{N}$} & \multirow[b]{2}{*}{ Gender } & \multirow[b]{2}{*}{ Age } & \multirow[b]{2}{*}{ Income } & \multirow[b]{2}{*}{ Experience } & \multirow[b]{2}{*}{$\begin{array}{l}\text { Marital } \\
\text { Status }\end{array}$} \\
\hline & $\begin{array}{l}\text { M-Banking rejection } \\
\text { factors }\end{array}$ & & & & & & \\
\hline 1 & $\begin{array}{l}\text { Lack of Information about M- } \\
\text { Banking }\end{array}$ & 159 & 0.54 & 0.406 & 0.19 & 0.051 & 0.659 \\
\hline 2 & I am unaware about M-Banking & 159 & 0.721 & 0.599 & 0.076 & 0.393 & 0.147 \\
\hline 3 & My banks do not offer M-Banking & 159 & 0.117 & 0.40 & 0.787 & 0.747 & 0.750 \\
\hline 4 & $\begin{array}{l}\text { M-Banking attract additional } \\
\text { banking charges }\end{array}$ & 162 & 0.886 & 0.105 & 0.376 & 0.069 & 0.514 \\
\hline 5 & M-Banking is difficult to use & 161 & 0.498 & 0.594 & 0.826 & $0.001^{*}$ & 0.766 \\
\hline 6 & I Don't have bank account & 160 & 0.447 & 0.146 & $0.002 *$ & $0.010 *$ & $0.000 *$ \\
\hline 7 & $\begin{array}{l}\text { I Don't have sufficient balance in } \\
\text { my account }\end{array}$ & 160 & 0.284 & $0.011 *$ & $0.002^{*}$ & 0.745 & 0.539 \\
\hline 8 & $\begin{array}{l}\text { Mobile phone battery can run } \\
\text { down } \\
\text { banking transactions }\end{array}$ & 161 & $0.005^{*}$ & 0.136 & $0.017^{*}$ & 0.297 & $0.000^{*}$ \\
\hline 9 & $\begin{array}{ll}\text { Poor } & \text { telecommunication } \\
\text { networks } & \end{array}$ & 159 & 0.465 & 0.520 & 0.116 & 0.513 & $0.001^{*}$ \\
\hline 10 & $\begin{array}{l}\text { My missing mobile phone can be } \\
\text { used by third party to steal } \\
\text { money from my account }\end{array}$ & 161 & 0.169 & 0.065 & 0.30 & 0.629 & 0.498 \\
\hline 11 & $\begin{array}{l}\text { My bank will sent me unnecessary } \\
\text { text } \\
\text { messages }\end{array}$ & 163 & 0.537 & 0.744 & 0.564 & 0.897 & 0.826 \\
\hline 12 & $\begin{array}{l}\text { I prefer to go to banks instead of } \\
\text { using } \\
\text { Banking }\end{array}$ & 163 & 0.604 & 0.134 & $0.000 *$ & 0.027 & 0.646 \\
\hline 13 & $\begin{array}{l}\text { None of my friends is using } \\
\text { mobile phone for } \\
\text { banking transactions }\end{array}$ & 160 & 0.469 & $0.050 *$ & $0.007^{*}$ & 0.003 & $0.006^{*}$ \\
\hline 14 & $\begin{array}{l}\text { The cost of purchasing a mobile } \\
\text { phone } \\
\text { suitable for M-banking is high }\end{array}$ & 158 & 0.173 & 0.027 & $0.003^{*}$ & 0.957 & 0.054 \\
\hline 15 & $\begin{array}{l}\text { M-Baking requires knowledge and } \\
\text { learning }\end{array}$ & 162 & 0.265 & 0.649 & $0.004^{*}$ & 0.299 & $\mathrm{~s}$ \\
\hline
\end{tabular}

The socio-demographic variables displayed general non-significant values (see table 4). Chisquare test was used to explore in detail the relation between M-Banking services and socioeconomic variables, however only relevant variables and their level of significance were explored in details (see table 4). 
RQ 2 How can the income level of the respondents influence rejection of M-Banking?

This question aimed at determining how income level of the respondents would influence rejection of M-Banking. As presented in table 5, cross tabulation of M-Banking rejecting motives against monthly income levels, the figures obtained in table 5 shows that percentage values for the rejection factors decline with increase in income.

Table 5 Present Cross-tabulation between M-Banking rejection factors and personal monthly income

\begin{tabular}{|c|c|c|c|c|c|c|c|c|c|}
\hline $\begin{array}{l}\text { M-Banking rejection } \\
\text { factors }\end{array}$ & $\begin{array}{l}<200 \\
(\%)\end{array}$ & $\begin{array}{l}200- \\
400 \\
(\%)\end{array}$ & $\begin{array}{l}401- \\
600 \\
(\%)\end{array}$ & $\begin{array}{l}601- \\
800 \\
(\%)\end{array}$ & $\begin{array}{l}801- \\
1000 \\
(\%)\end{array}$ & $\begin{array}{l}1001- \\
1200 \\
(\%)\end{array}$ & $\begin{array}{l}1201- \\
1401 \\
(\%)\end{array}$ & $>1401$ & $x^{2}($ sig. $)$ \\
\hline 1. Lack information about & & & & & & & & & \\
\hline $\begin{array}{l}\text { M- Banking } \\
\text { 2. I don't have bank }\end{array}$ & 31.3 & 22.7 & 18.2 & 13.6 & 13.2 & 9.1 & 0 & 0 & $0.019 *$ \\
\hline $\begin{array}{l}\text { Account } \\
\text { 3. I don't have sufficient }\end{array}$ & 30.0 & 10.0 & 10.0 & 50.0 & 20.0 & 20.0 & 0 & 0 & $0.002^{*}$ \\
\hline $\begin{array}{l}\text { balance in my account } \\
\text { 4. I prefer to go to bank } \\
\text { instead of using M- }\end{array}$ & 56.2 & 12.5 & 6.2 & 20 & 18.8 & 0.0 & 0 & 0 & $0.002^{*}$ \\
\hline Banking & 50.0 & 20.8 & 4.2 & 4.2 & 4.2 & 12.5 & 0 & 0 & $0.000^{*}$ \\
\hline $\begin{array}{l}\text { 5. None of my friends is } \\
\text { using mobile phone for } \\
\text { banking transactions }\end{array}$ & 62.5 & 0.0 & 12.5 & 0.0 & 0.0 & 0.0 & 0 & 12.5 & $0.007^{*}$ \\
\hline $\begin{array}{l}\text { 6. The cost of purchasing } \\
\text { mobile phone suitable } \\
\text { for M-Banking is high }\end{array}$ & 57.1 & 14.3 & 7.1 & 0.0 & 14.3 & 0.0 & 0 & 0 & $0.003^{*}$ \\
\hline 7. M-Banking requires & & & & & & & & & \\
\hline knowledge an learning & 48.1 & 22.2 & 11.1 & 11.6 & 11.1 & 0.0 & 0 & 0 & $0.004^{*}$ \\
\hline
\end{tabular}

The only exception was "none of my friends is using mobile phone for banking transactions which increase for those with income level above GHc14001. This implies that low income level consumers are more likely to reject M-Banking services than those with high income. This is in support of study by (Sim and Koi, 2002; Venkatraman, 1991) that innovative technologies are first adopted mainly by younger and educated people with higher income levels.

These results indicate the need for market segmentation and the application of differentiated marketing procedure to attract potential customers with low income so as to widen the market base for M-Banking services in Ghana, generally income levels in Ghana are relatively low among large portion of the population, therefore any strategy aims at reaching these potential 
market base should be vigorously crafted and pursued by marketing managers in the banking sector.

\section{RQ3 How can the marital status of the respondents influence rejection of M-Banking?}

This question aimed at determining how marital status of the respondents would influence rejection of M-Banking. As presented in table 6, cross tabulation of M-Banking rejecting motives against marital status shows that unmarried respondents' shows higher proportion in terms of the rejection motives than married in all the rejection factors in table 6 . We therefore conclude that the unmarried are likely to reject M-Banking based on the following factors: not having bank account, poor mobile battery life, friends not using M-Banking, poor telecommunication networks and M-Banking require knowledge and learning.

Table 6 Present Cross-tabulation between M-Banking rejection factors and marital status of the respondents

\begin{tabular}{|c|c|c|c|}
\hline M-Banking rejection factors & $\begin{array}{l}\text { Unmarried } \\
(\%)\end{array}$ & $\begin{array}{l}\text { Married } \\
(\%)\end{array}$ & $x^{2}$ (sig.) \\
\hline 1. I don't have bank Account & 75.0 & 25.0 & $0.000 *$ \\
\hline $\begin{array}{l}\text { 2. Mobile phone Battery can run down during } \\
\text { transactions }\end{array}$ & 80.0 & 20.0 & $0.000 *$ \\
\hline 3. Poor telecommunication & 71.4 & 28.8 & $0.001 *$ \\
\hline $\begin{array}{l}\text { 4. None of my friends is using mobile phone for banking } \\
\text { transactions }\end{array}$ & 75.0 & 12.5 & $0.006^{*}$ \\
\hline 5. M-Baking requires knowledge and learning & 85.7 & 14.3 & $0.026 *$ \\
\hline
\end{tabular}

RQ4 How can the Age of the respondents influence rejection of M-Banking?

This question aimed at determining how age of the respondents would influence rejection of M-Banking. As presented in table 7, cross tabulation of M-Banking rejecting motives against the age categories of the respondents.

Table 7 Present Cross-tabulation between M-Banking rejection factors and Age group of the respondents

\begin{tabular}{|c|c|c|c|c|c|}
\hline M-Banking rejection factors & $\begin{array}{l}21- \\
25 \\
(\%)\end{array}$ & $\begin{array}{l}26- \\
35 \\
(\%)\end{array}$ & $\begin{array}{l}36- \\
45 \\
(\%)\end{array}$ & $>50$ & $x^{2}$ (sig.) \\
\hline 1. I don't have sufficient balance in my account & 52.6 & 42.1 & 5.3 & 0.0 & $0.011^{*}$ \\
\hline $\begin{array}{l}\text { 2. The cost of purchasing mobile phone suitable for M- } \\
\text { Banking } \\
\text { high }\end{array}$ & 66.7 & 20.0 & 6.7 & 6.7 & $0.027^{*}$ \\
\hline Note: *The significance in the independence test was evalu & ated & 0.05 & & & \\
\hline
\end{tabular}


The younger respondents (21-25) age group have indicated that having insufficient balance in their account is one the main motives for rejecting M-Banking; this barrier decreases with increase in age. The high cost of purchasing smart phones accounted for higher proportion among the same age group. This clearly shows that youth have the tendency to reject $\mathrm{M}$ Banking services due to their low income status.

RQ5 How can the gender of the respondents influence rejection of M-Banking?

This question aimed at determining how the gender of the respondents would influence rejection of M-Banking. As presented in table 8 , cross tabulation of M-Banking rejecting motives against the gender of the respondents.

Table 8 Present Cross-tabulation between M-Banking rejection factors and Gender of the respondents

\begin{tabular}{|c|c|c|c|}
\hline M-Banking rejection factors & $\begin{array}{l}\text { Male } \\
(\%)\end{array}$ & $\begin{array}{l}\text { Female } \\
(\%)\end{array}$ & $x^{2}$ (sig.) \\
\hline Mobile phone Battery can run down during banking transactions & 90 & 10 & $0.005^{*}$ \\
\hline \multicolumn{4}{|c|}{ Note: *The significance in the independence test was evaluated at 0.05 level } \\
\hline
\end{tabular}

Male respondents seem to be more concern about the mobile phone battery running down during transaction (90 percent) than their female counterpart. The reason being that male respondent are found to be active in exploring new technologies and are more concern about longitivity of the battery life than female respondents in the process of exploring and actually using mobile device for communication and entertainment purposes.

RQ6 How can the number of years 'experience' of using mobile phone influence rejection of M-Banking?

This question aimed at determining how number of years respondents have been using mobile phone (experience) would influence rejection of M-Banking. As presented in table 9, cross tabulation of $\mathrm{M}$-Banking rejecting motives against experience. 
Table 9 Cross-tabulation between M-Banking rejection factors and number of years (experience) of using mobile phones

\begin{tabular}{|c|c|c|c|c|c|}
\hline M-Banking rejection factors & $\begin{array}{l}<1 \mathrm{Yr} \\
(\%)\end{array}$ & $\begin{array}{l}1-3 \text { Yrs } \\
(\%)\end{array}$ & $\begin{array}{l}3-5 \text { Yrs } \\
(\%)\end{array}$ & $\begin{array}{l}>5 Y r s \\
(\%)\end{array}$ & $x^{2}$ (sig.) \\
\hline Lack of information about M-Banking & 0.0 & 4.5 & 22.7 & 72.7 & $0.040^{*}$ \\
\hline 2. M-Banking is difficult to use & 7.1 & 0.0 & 10.7 & 82.1 & $0.001^{*}$ \\
\hline 3. I don't have bank Account & 0.0 & 0.0 & 20.0 & 80.0 & $0.010^{*}$ \\
\hline $\begin{array}{l}\text { 4.I prefer to go to braches instead of using } \\
\text { M-Banking }\end{array}$ & 3.7 & 11.1 & 11.1 & 74.1 & $0.027^{*}$ \\
\hline $\begin{array}{l}\text { 5. None of my friends is using mobile } \\
\text { phone for banking transactions }\end{array}$ & 0.0 & 0.0 & 11.1 & 88.9 & $0.003^{*}$ \\
\hline Note: ${ }^{*}$ The significance in the independence te & st was & valuate & 0.05 & & \\
\hline
\end{tabular}

Lack of information account for (0 percent) for those with less than a year's experience of using mobile and it increases significantly to (72.7 percent) for respondents with more than 5 years or more experience. "M-Banking is difficult to use" accounted for (7.1 percent) for respondents with less than 1 year experience and (82.1 percent) for those with more than five year experience. Respondents "not having Bank account" as a barrier accounted for (20 percent) for those with 3-5 years and (80 percent) for those with more than five years' experience. Respondents "preference for visiting bank branches instead of using M-Banking" resulted in (3.7 percent) for those with less than 1 year experience and (74.1 percent) for those with more than 5 year experience. We can conclude that respondents with more than 5 year experience are more likely to reject M-banking base on the rejection factors identified in table 9.

\section{Discussions}

Results and managerial implications

M-Banking as an innovative way of banking is emerging rapidly and is expected to grow exponentially in the near future. However M-banking diffusion is low inspite of high mobile penetration in Ghana. This research empirically investigated the main barriers to adoption of mobile banking among consumers in developing country context.

The combination of the various rejection factors associated with M-Banking transactions in this research have implications for marketing managers for development and marketing of $\mathrm{M}$ banking services targeting potential and existing customer base of the banks. This research serves as eye opener for Banks in Ghana on the deployment of M-banking activities.

Among the main reasons for rejecting $M$-Banking among young consumers includes, " $M$ Banking requires knowledge and learning". Tobin (2012), indicates that the level of knowledge of M-Banking services is a major factor on how consumers perceived the ease with which to use M-Banking services. Therefore Banks need to craft appropriate strategy that will create required knowledge for using mobile banking services by potential and existing customer base. 
"Attracting additional Banking charges" was one of the main reasons for rejecting M-Banking services. This finding is in line with Cruz et. al, (2010) that customers rejected M-Banking due to perception of high cost even though the Banks do not charge for SMS banking. However, in Ghana Banks currently charge about GHc0.08 per SMS alert sent via customers mobile phones.

The third reason for rejection of M-Banking is poor nature of telecommunications infrastructure in the country. The respondents stated poor nature of the infrastructure as disincentive for using their mobile phones in undertaking banking transactions. This is as a result of frustrations and disappointment customers go through in using mobile phones for communication and entertainment purposes during peak periods.

Considering income levels, respondents with low income level perceived all the factors identified in table 4 as an obstacle to M-Banking usage showing higher percentage values than the other income level groups. In contrast, respondents with higher income levels do not perceive these factors as obstacles to M-Banking adoption. Therefore, Banks should device appropriate marketing strategy targeting potential customers that fall within low income bracket because right marketing strategies targeting this group of customers can lead to wider adoption of M-Banking.

Rejection of M-Banking related to the respondents not having bank account tend to be higher for unmarried and declines for married. In the case of mobile phone battery running down during transactions unmarried perceived this factor as major obstacle to M-Banking adoption.

This research has contributed to theory, in that considering the dearth of literature that currently exists about M-Banking in Ghana, this study would make a significant contribution in understanding the nature of the customers' mindset when making decision between adoption and non-adoption of M-Banking based on the rejection factors identified in this research.

However this paper is not without limitations, the research focused on young consumers in Ashanti region of Ghana, posing limited generalisability to other demographic segments and cultures. More rigorous quantitative and qualitative analysis should be used to better understand M-Banking rejection factors taking into account other factors.

\section{References}

Akturan, U., and Tezcan, N., (2012),"Mobile Banking Adoption of the Youth Market: Perceptions and Intentions", Marketing Intelligence \& Planning, Vol. 30 Iss: 4 (Date online

15/5/2012)

Brown, I., Cajee, Z., Davies, D. and Stroebel, S. (2003), "Cell phone banking: Predictors of adoption in South Africa- An exploratory study", International Journal of Information Management, Vol.23, No.5, pp. 381-394.

Cruz, P., Laukkanen, T. and Mun oz-Gallego, P. (2009), "Exploring the factors behind the resistance to mobile banking in Portugal", International Journal of E-services and Mobile $\begin{array}{llllll}\text { Applications, } & \text { Vol. } & 1 & \text { No. } & 4, & \text { pp. }\end{array}$ Goldsmith, R.E. (2001), "Using the domain specific innovativeness scale to identify innovative 
internet consumers", Internet Research: Electronic Networking Applications and Policy, Vol. $11 \quad$ No. 14 2, $\quad$ pp. Iddris, F., (2012) An Exploration Of B2c Mobile Commerce Adoption In Ghana: An Empirical Integration Of Technology Acceptance Model (TAM) And Theory Of Planned (TPB) Behaviour Asian Journal of Research in Business Economic and Management Volume 2 , Issue

Internatinal telecommunication Union, (2011) www.itu.int/ITUD/ ict/newslog/CategoryView,category,Mobile\%2Bapplications.aspx(last access, December, 2012)

Laforet, S. and Li, X. (2005), "Customers' attitudes towards online and mobile banking in China", International Journal of Bank Marketing, Vol.23, No.5, pp. 362-380 Laukkanen, T. and Kiviniemi, V., (2010) The role of information in mobile banking resistance International Journal of Bank Marketing Vol. 28 No. 5, 2010 pp. 372-388 Laukkanen, T. and Pasanen, M. (2008), "Mobile banking innovators and early adopters: How they differ from other online users?", Journal of Financial Services Marketing, Vol. 13 No. 2,pp.

86-94.

Karjaluoto, H., Mattila, M. and Pento, T. (2002), "Factors underlying attitude formation towardsonline banking in Finland", International Journal of Banking Marketing, Vol. 20 No. $6, p p$.

261-72.

Luo, Y. (2009), "Using internet data collection in marketing research", International Business $\begin{array}{llllll}\text { Research, } & \text { Vol. } & 2 & \text { No. } & 1, & \text { 196-202. }\end{array}$

Luo, X., Li, H., Zhang, J. and Shim, J.P. (2010), "Examining multi-dimensional trust and multi-faceted risk in initial acceptance of emerging technologies: an empirical study of mobile banking services", Decision Support Systems, Vol. 49 No. 2, pp. 222-34. Laukkanen, Malhotra, Naresh K \& David F. Birks (2008) Marketing Research an Applied Approach (3 Edition)

England.

Meuter, M., Bitner, M., Ostron, A. and Brown, S. (2005), "Choosing among alternative service delivery modes: an investigation of customer trial of self-service technologies", Journal of $\begin{array}{llllll}\text { Marketing, } & \text { Vol. } & 69 & \text { No. } & 2, & \text { pp. }\end{array}$

Munnukka, J., (2007),"Characteristics of early adopters in mobile communications markets", Marketing Intelligence \& Planning, Vol. 25 Iss: 7 pp. 719 - 731 Nysveen, H., Pedersen, P.E. and Thorbjørnsen, H. (2005b), "Explaining intention to use mobile chat services: moderating effects of gender", Journal of Consumer Marketing, Vol. 22 No.
5 , Communication pp.

247-56.

National
Authority

(2013)

http://www.nca.org.gh/downloads/MarketShare/September\%202012\%20web\%20version.pdf

(Accessed 2013)

Pu"schel, AfonsoMazzon and C. Hernandez (2010) Mobile banking: proposition of an integrated adoption intention framework International Journal of Bank Marketing Vol. 28 No. 5 , $2010 \quad$ pp. 389-409 Paterson, L., and Low, B., (2011) "Student attitudes towards mobile library services for smartphones", Library $\mathrm{Hi}$ Tech, Vol. 29 Iss: 3, pp.412 - 423 Sarker, S. and Wells, J. D. 2003. "Understanding Mobile Handheld Device Use and Adoption," Communication of the ACM (46:12), pp. 35-40. 
Sim, L.L. and Koi, S.M. (2002), "Singapore's internet shoppers and their impact on traditional shopping patterns", Journal of Retailing and Consumer Services, Vol. 9 No. 2, pp. 115-24.

T., and Kiviniemi, V. (2010) "The role of information in mobile banking resistance", International Journal of Bank Marketing, Vol. 28 Iss: 5, pp.372 - 388

Thulani, D.,Kosmos, N., Collins, M., Lyod, C., (2011) Adoption And Use of SMS/Mobile Banking Services in Zimbabwe: An Exploratory Study Journal of Internet Banking and Commerce, August 2011, vol. 16, no.2

Tiwari, R. and Buse, S., Humbury University Press (2007), The mobile commerce prospects: A strategic Analysis of opportunities in the banking sector', [online](cited 23 September 2008) Available from (URL: http://hup.sub.uni-hamburg.de/productspage/ publikationen/56).

Tobbin, P.,(2012),"Towards a model of adoption in mobile banking by the unbanked: a qualitative study", info, Vol. 14 Iss: 5 pp. $74 \quad-88$ Wilcox, H. (2009a), "Banking on the mobile", white paper, Juniper Research, Basingstoke, available at www.juniperresearch.com (accessed 23 October 2012).

Venkatraman, M.P. (1991), "The impact of innovativeness and innovation type on adoption", Journal of Retailing, Vol. 67 No. 1, pp. 51-67.

Yang, K. (2005). "Exploring factors affecting the adoption of mobile commerce in Singapore." Telematics and Informatics 22(3): 257-277.

$\mathrm{Yu}, \mathrm{S}$. (2009). Factors influencing the use of Mobile Banking: The case of SMS-based Mobile Banking. School of Computing and Mathematical Sciences. Auckland, Auckland University of Technology. Master of Computer and Information Sciences (MCIS).

Zaou, T., (2011)An empirical examination of initial trust in mobile banking Internet Research Vol. 21 No. 5, 2011 pp. 527-540

Zhang, J. and Mao, E. (2008), "Acceptance of mobile SMS advertising among young Chinese consumers", Psychology \& Marketing, Vol. 25 No. 8, pp. 787-805. 